\title{
Advocating Sustainable Building Paradigm through Value Management
}

\author{
Saipol Bari Abd-Karim ${ }^{1 *}$, Hew Wan Wah², Aini Jaapar ${ }^{3}$, Mohamad Saiful Nizam Mohd \\ Suhaimi ${ }^{4}$, M. Ali Berawi ${ }^{5}$ \\ ${ }^{1,2}$ Centre for Building, Construction \& Tropical Architecture (BuCTA), Faculty of Built \\ Environment, University of Malaya, 50603 Kuala Lumpur, Malaysia. \\ ${ }^{3}$ Centre of Studies in Quantity Surveying, Faculty of Architecture, Planning \& Surveying, \\ Universiti Teknologi MARA, 40450 Shah Alam, Selangor Malaysia. \\ ${ }^{4}$ Department of Quantity Surveying, Kulliyyah of Architecture \& Environmental Design, \\ International Islamic University Malaysia, Gombak, 53100 Kuala Lumpur, Malaysia. \\ ${ }^{5}$ Department of Civil Engineering, Faculty of Engineering, Universitas Indonesia, Depok, \\ 16424 Indonesia. \\ *saipolbari@um.edu.my
}

\begin{abstract}
Sustainability issues had become one of the top issues of Malaysia construction industry. The implication of sustainable dimensions into construction project helps in generating buildings which are energy efficient, healthy, comfortable and flexible while at the same time increases its durability. Value management (VM) is proposed as a tool used to promote sustainable building (SB). VM aims to achieve optimum value of a project based on its objectives and its approach is much similar with sustainability which ideally focusing on achieving values, not just economically, but environmentally and social aspects of the project. This paper investigated the practicability of the VM-SB integration in the Malaysia construction industry. It explores the development and practices of VM-SB concept as well as assessing the performance criteria of integrating VM in SB projects. Findings from the questionnaire surveys which were distributed to G7 contractors showed that the VM-SB integration is still low but gradually increasing. More knowledge and understanding of both concepts are needed prior to be implemented into a project as there are potentials for VM-SB concept to be adapted to all projects in the near future.
\end{abstract}

Keywords: Value management, sustainable building, construction industry

\section{INTRODUCTION}

Malaysia as a developing nation, the continuous demand for construction projects has helped in contributing to the economy. Presently, there are more contractors and construction-related consulting firms where competitions among them are increasingly becoming more intense with variety of scope offerings. Hence, there is a need to have an effective company strategies and operations to keep in line with the industry. Management tools should be well utilized in order to control the value of money of the project while at the same time achieving its function ability. Value management (VM) is a systematic process used by a multi-disciplinary team to improve the value of a project through the analysis of functions (SAVE, 2007). VM is widely accepted and practised in many countries (Abd-Karim, Rahmin, Mohd Danuri and Mohamed, 2014). It is introduced since 1986 in Malaysia and has been increasingly accepted ever since the authorization of VM circular 3/2009 by the Economic Planning Unit (EPU) of the Prime Minister's Department, for which VM is made mandatory for all public projects exceeding RM50 million. Through this mandatory enforcement, a saving of $23.53 \%$ from the total cost of more than 50 public projects has been recorded as a result of VM implementation during initial phase of the projects (Ahmad, 2011).

The Construction Industry Development Board of Malaysia (CIDB), which is an organization, established aiming at developing, improving and expanding the Malaysian construction industry has identified the environment and other sustainability-related issues as the top issues within the construction industry (CIDB Malaysia, 2007). Recently, CIDB Malaysia is leading the transformation of local practices and enhancing the capacity to deliver sustainable infrastructure, an issue that 
has come under intense focus following devastating year-end floods in the country. On the other hand, sustainable building (SB) is considerably a new concept in Malaysia with the introduction of a Green Building Index (GBI); a professional-driven building rating system back in 2009; GBI has been developed and implemented to promote sustainability in the Malaysian building sector (GSB, 2009). However, due to barriers in delivering SB in Malaysia such as lack of interest among clients to demand for a sustainable built environment, lack of political will, lack of technical understanding among project team members and other practical barriers related to the availability of sustainable materials, products and technologies that need to be addressed, SB is yet to be considered as a priority choice in the Malaysian construction industry (Shari and Soebarto, 2012). Therefore, there is a need to promote the implementation of SB in Malaysia.

\section{PROBLEM STATEMENT}

Ever since VM is being introduced in Malaysia during early $80 \mathrm{~s}$, the level of acceptance and strong application are still considered to be at infancy stage. This is partly due by the segmented level of understanding of industry player's specifically on the knowledge or understanding about VM. There are still misconceptions and misconducts of VM. Jaapar, Maznan and Zawawi, (2012) highlighted that the negative attitudes towards $\mathrm{VM}$ is particularly greater in private construction sector. Sharing similar dilemma with VM, the SB sector is also experiencing challenges on the level of acceptance of sustainability concept and its acceptance is not industry-wide as many developers, especially the small and medium size are still reserving themselves. The critical dilemma faced by SB sector are even greater than VM where it is believed to be low because of several impeding factors such as lack of knowledge, poor enforcement of legislation, education, experience and passive culture. Categorically, it affects mainly the small to medium size developer's companies where the concern is on the perception that SB will require heavy capital investment and infrastructure. On the other hand, large companies have the capability (capital, experience and expertise) to apply sustainable principles in their project, while small-medium companies are inclined on fulfilling minimum standard required by the government and to ensure that their project is sellable to various levels of income earners (Zainul Abidin, 2010). Studies related to the implementation of VM-SB for sustainable building are still lacking. El-Alfy (2010) pointed out that a practical approach in improving building sustainability need to be developed. According to El-Alfy (2010), the use of job plan in value engineering (VE) together with a database on construction systems and materials together with job plan will provide a better solution for sustainable building initiative. Additionally, VE can also contribute to towards a more sustainable building (Bahaudin, Elias and Saifudin, 2014). Meanwhile Al-Saleh and Taleb (2010) pointed out that although VM has been proposed as potential mechanism in delivering sustainable construction projects, the idea has yet to be widely realized. Likewise, Karunasena, Rathnayake and Senarathne (2014) found out that there is no standard process used in sustainable construction and value planning (VP) applications due to lack of awareness among clients.

The positive side of this dilemma faced by VM and SB has its own blessings where a study by Md. Noor, Kamaruzzaman and Ghaffar (2015) found that the sustainable knowledge between VM practitioners and the attention given to the project sustainability were at the moderate level. Additionally, Md. Noor et al (2015) pointed out that sustainable concern has yet to become a priority of one's project and therefore there is a need to enhance the VM-SB integration in building projects which is hoped to lead a better inclusion of sustainability practice into present governments' project. The shift from the moderate to a much higher level of appreciation of sustainable knowledge is observed to having its own potential of advocating SB through VM application.

\section{OBJECTIVES}

This research paper examines the practicability of VM-SB integration in the Malaysia construction industry by investigating the current development and practices of VM and $\mathrm{SB}$ in Malaysia, assessing their integration and also determining their performance criteria.

\section{VALUE MANAGEMENT IN MALAYSIA CONSTRUCTION INDUSTRY}

Abd-Karim (2016) asserts that the government of Malaysia has mandated the implementation of VM for public projects valued RM50 million and above. This is supported with the publication of the VM implementation guide for government programmes and projects in 2011 as well as the updated Economic Planning Unit 
(EPU) Circular 1/2015, which was initiated by the EPU in collaboration with CIDB and the Institute of Value Management Malaysia (IVMM) in 2009 to be used in construction projects as its implementation helps in producing various benefits to the project. Prior to this, the Malaysia Airports Holdings Berhad (MAHB) was the first organization to introduce its own guideline in implementing VM. The manual outlined the VM methodology framework for the organisation as a result from successful VM studies conducted for selected MAHB works, supplies, systems and facilities above RM300,000 (MAHB, 2008). The Public Works Department (PWD) also responded well to this initiative for which it releases its own guideline for public projects in 2013, focusing on value engineering (VE) (PROKOM, 2013).

There are several factors and challenges which lead to obstacles of VM implementation in Malaysia. According to Jaapar, Endut, Bari, and Takim (2009), one of the challenges that lead to unsuccessful implementation of VM workshop in public project was due to the insufficient information provided, as there are insufficient of information provided, thus an inaccurate judgement could be made especially information regarding of costing. Besides, it is not an easy job to satisfy every VM practitioners involved in the VM workshop. Thus, outcomes to satisfy them are hardly to be made as it consumes time and requires full participation (Jaapar et al., 2012).

According to Oke and Aigbavboa (2017), the sustainable implementation of VM in construction projects requires willingness to apply and to employ the methodology. The barriers and challenges towards its implementation can be overcome through the identified drivers namely training and education, creating the necessary awareness, the involvement of stakeholders, and the formulation of the necessary and appropriate guidelines and regulations (Oke and Aigbavboa, 2017). Individual personalities may also contribute as one of the challenges during the VM implementation. Jaapar et al., (2012) highlighted that it is also challenging for VM facilitator to handle various types of people with different characters, view of points and background. Thus, in order for a smooth session, VM facilitator must be able to attract the VM participants to be active during the workshop. Meanwhile, it was found out that some industry practitioners misunderstood the actual VM methodology. Jaapar et al., (2012) pointed out that this has led to wrong interpretation of VM for which VM was understood to be a cutting tool in reducing the construction cost. However, it is not a recent problem as the misconception has existed more than ten years ago for which Jaapar and AbdKarim (2005) stated that many practitioners in the industry are confused between VM and cost reduction exercises These misconceptions among the practitioners are due to insufficient of knowledge and disclosure on VM (Jaapar and Abd-Karim, 2005).

\section{THE CONCEPT AND PRACTICE OF SUSTAINABLE BUILDING (SB)}

Sustainable development is a multi-dimensional and multi-disciplinary concept (Bala, 2017), for which it was built upon the Bruntland Commission report published by the United Nations in 1987 that linked the issues of economic development and environmental sustainability. The understanding of sustainability has been argued as another ideology (Platova, 2013; Loukola and Kyllönen, 2005) and not merely a concept. According to Platova (2013), the concept of sustainable development is similar to ideology, which concerns ideas, principles and values based on critical thinking, scientific knowledge and philosophical doctrine. Moreover, the value of sustainability itself is assumed in the economic thinking and was built into the concept of income (Daly, 1990). However, do to the constant changing of how sustainability is conceptualised (Loukola and Kyllönen, 2005) hence sustainable development is considered as a concept that branched out from the theory and philosophy of sustainability.

Various sustainable based concepts have been applied in order to achieve sustainability purposes such as sustainable and green building, sustainable and green construction and sustainable and green project management and others (Isa, Samad and Alias, 2014). However, as the definition of SB involves a general coverage of building built using ecological concept and resource-efficient materials, there are also several general principles of sustainable building.

It is strongly believed that most construction works related to the concept of SB, are influenced by the basic concept of sustainability based on scarcity of resources where it helps to reduce impact to the environment with mainly focused on the technical issues such as materials and building components, construction technologies and energy efficient concepts (Darus, Hashim, 
Salleh, Haw, Rashid, and Manan, (2009); Abidin, 2009).

In addition, Akadirii, Chinyio and Olomolaiye (2012) and, Hill and Bowen (1997) added that SB concept consists four principles which are social, economic, biophysical and technical. Moreover, Kibert (2005) has emphasized that SB is related to the creation of a healthy built environment upon usage of efficient resources based on ecological design with an emphasis on seven basic principles of the building life cycle which are:
i). Decreases resources consumption,
ii). Reusing resources,
iii). Using recyclable resources,
iv). Protecting nature,
v). Eliminating toxics,
vi). Adopting life cycle costing,
vii). Emphasis on quality

\section{Barriers faced by SB implementation in Malaysia}

Various authors have written on promoting and encouraging the development of SB within the construction industry context. Such concept is gaining its momentum in the Malaysian sector specifically within the private developers' fraternity. However, despite of its growing popularity, the implementation of $\mathrm{SB}$ has to defy various barriers and challenges. A study conducted by Häkkinen and Belloni (2011) found that there are generally nine (9) form of barriers to SB which includes a) steering b) costs, risks and value, c) demand, d) tendering and procurement, e) process phases and tasks, f) cooperation and networking, g) knowledge and common terminology, h) availability of integrated methods and i) innovation process. These barriers are extended beyond the strategic decision-making phase of the project where it also affect critical point of construction project milestones.

Similarly, in the local context, Shari and Soebarto (2012) in their study has fine tune the barriers of implement SB that are centered towards front-end decision-making phase of a project. Table 1 indicates some of the barriers to SB practices in Malaysia.

Table 1: Barriers to SB Practices in Malaysia (Source: Shari and Soebarto, 2012)

\begin{tabular}{|l|l|}
\hline \multicolumn{1}{|c|}{ Barriers } & \multicolumn{1}{c|}{ Explanation } \\
\hline $\begin{array}{l}\text { Low demand from } \\
\text { client on }\end{array}$ & $\begin{array}{l}\text { Total absence or lack of } \\
\text { interest in the client's } \\
\text { sustainability } \\
\text { measure. }\end{array}$ \\
$\begin{array}{l}\text { demand for SB. The study } \\
\text { emphasized that the two }\end{array}$ \\
\hline
\end{tabular}

\begin{tabular}{|c|c|}
\hline & $\begin{array}{l}\text { reasons which lead to the } \\
\text { lack of demand are: } \\
\text { (1) Insufficiency of } \\
\text { education or } \\
\text { awareness about the } \\
\text { advantages of SB. } \\
\text { (2) Perception of SB } \\
\text { practices will increase } \\
\text { costs and reduce } \\
\text { profits. }\end{array}$ \\
\hline $\begin{array}{l}\text { Limited political } \\
\text { will, legislation and } \\
\text { enforcement at } \\
\text { various } \\
\text { governmental } \\
\text { levels. }\end{array}$ & $\begin{array}{l}\text { Government had limited } \\
\text { understanding of SB. }\end{array}$ \\
\hline $\begin{array}{l}\text { Lack of technical } \\
\text { understanding by } \\
\text { team members. }\end{array}$ & $\begin{array}{l}\text { Study emphasized that it } \\
\text { was mainly due to a } \\
\text { general lack of interest in } \\
\text { undertaking education } \\
\text { programmes and technical } \\
\text { trainings on SB. }\end{array}$ \\
\hline $\begin{array}{l}\text { Limited knowledge } \\
\text { and application of } \\
\text { sustainable oriented } \\
\text { practice among } \\
\text { project r team } \\
\text { members. } \\
\end{array}$ & $\begin{array}{l}\text { Low interest in SB by } \\
\text { team members due to lack } \\
\text { of technical understanding } \\
\text { and awareness of SB. }\end{array}$ \\
\hline $\begin{array}{lr}\text { Cost } & \text { for } \\
\text { sustainability } & \\
\text { measure } & \text { is } \\
\text { perceived as } & \text { too } \\
\text { expensive. } & \end{array}$ & $\begin{array}{l}\text { Although cost analysis on } \\
\text { SB and usual building } \\
\text { works had not been } \\
\text { thoroughly studied, } \\
\text { developers have a thought } \\
\text { that anything other than } \\
\text { 'usual businesses will be } \\
\text { more expensive. }\end{array}$ \\
\hline $\begin{array}{l}\text { Sustainability } \\
\text { measure was not } \\
\text { practiced by the } \\
\text { occupier. }\end{array}$ & $\begin{array}{l}\text { Lack of interest and } \\
\text { awareness in conserving } \\
\text { energy, water, and } \\
\text { reducing waste. }\end{array}$ \\
\hline $\begin{array}{l}\text { Limited availability } \\
\text { of local resources } \\
\text { on sustainable } \\
\text { materials, } \\
\text { components and } \\
\text { systems. }\end{array}$ & $\begin{array}{l}\text { Most } \\
\text { technologies and major } \\
\text { materials are not locally } \\
\text { available in Malaysia and } \\
\text { are imported hence lead to } \\
\text { an expensive cost. }\end{array}$ \\
\hline $\begin{array}{l}\text { Lack of information } \\
\text { to achieve } \\
\text { sustainable measure } \\
\text { by the stakeholders. }\end{array}$ & $\begin{array}{l}\text { A 'safe' solution was } \\
\text { normally } \\
\text { explaining why many } \\
\text { sustainability objectives } \\
\text { simply fell by the wayside. }\end{array}$ \\
\hline $\begin{array}{l}\text { Limited incentive } \\
\text { mechanism offered } \\
\text { for taking up } \\
\text { sustainable } \\
\text { construction. }\end{array}$ & $\begin{array}{l}\text { Little incentives are given } \\
\text { for building professionals } \\
\text { in order to pursue higher } \\
\text { performance standards or } \\
\text { reward for their innovation } \\
\text { in building designs. }\end{array}$ \\
\hline
\end{tabular}




\section{RELATIONSHIP BETWEEN VALUE MANAGEMENT \& SUSTAINABLE BUILDING}

\section{Capability of VM to implement SB}

The linkage between VM and SB is not a new concept in construction industry as there are various ideas have been proposed to incorporate the two elements earlier. For example, Al-Saleh and Taleb (2010), Barton, Jones and Anderson (1999) \& Yeomans (2002) discussed the potential of VM in promoting and delivering a sustainable project that contribute to increase value of a project. Hayles, Graham and Fong, (2010) stated that VM can be used as a delivering tool which make it as a sustainable construction solution and strategy. Besides, Abidin and Said (2006) also stated that VM provided many qualities which can increase the integration of sustainability issues with the project plans, designs and resolutions. Abidin and Pasquire (2005) also emphasized that the unique characteristics and stages in VM contributes it towards a beneficial way to promote sustainability. The greatest impact would be the chances of sustainability issues are to be included into $\mathrm{VM}$ practices in the early stage of a project.

The integration between the two elements comes about as the overall aims of VM and sustainability tend towards the same direction (Md. Noor et al., 2015). VM, which contemplate at achieving optimum value of a project based on its objectives are much similar with sustainability which ideally focus on achieving value not just economically, but environment and the social aspects of the projects. By integrating $\mathrm{VM}$ and $\mathrm{SB}$, a good economic return can be achieved by proposing a building which is built using sustainable materials and method of construction which helps to reduce and minimize the social and environmental damage. The fundamental concept of this integration is to emphasise on proposing sustainable elements by conducting $\mathrm{VM}$ process as an impact in minimizing the conflicts occurred between cost and sustainability when designing (Abidin and Pasquire, 2005). Subsequently, the best solution would be decided based on the consideration that best achieved the customer's economic needs and at the same time achieving environmental and social needs.

Apart from that, the VM-SB integration does not alter the VM processes as it only emphasizes and focuses on the scope and study of sustainable issue. In VM process, the VM practitioners may have to adopt their sustainability knowledge when giving explanation about functions, developing ideology and implement proposals. During preworkshop of VM, the importance of sustainability consideration will be presented to the customers. During function analysis stage, the identified sustainability will be included as part of the objectives and it should be made clearly and understandable to all project team members. The ideology that developed during creativity stage will be evaluated based on the functions and aims. After that, proposals are then setting up and proposed to the parties involved, which aims at saving the estimated cost at the same time focusing on the protecting the environment and social aspect thus provide a long-term economic return.

\section{Strength of VM for SB}

Sustainability concern should be included as early as possible in project stages in order to obtain a desire result. According to Abidin and Pasquire (2003), the strategic time frame for $\mathrm{VM}$ in obtaining desired impact in a construction project will be at the early stage in a project. VM workshops helps in ensuring sustainability issue does not fritter away as the project becomes more complex. Remarkably, VM establishes the agreed strategies in achieving a long term and sustainable solution (Phillips, 1999) and offers an option of a more SB and also provides opportunity to enhance the construction process (Hayles et al, 2010).

However, there are arguments that SB leads to a higher cost compared to the traditional building construction. This has become an obstacle for the society to undertake this concept. Acceptance of the concept is believed can be advanced by proving that it is economically valuable (Barton et al., 1999). As $\mathrm{VM}$ is good in eliminating unnecessary cost, thus there are higher chances that a SB can be constructed without any unnecessary cost increase and the concept is proven to be economically feasible.

There are three main parties involved in VM workshops, namely the decision makers, the practitioners and the team members (Pasquire and Mauro, 2001; British Standard EN 12973, 2000). Parties that involved take roles in achieving success integration of sustainability and VM. Additionally, Leung and Liu (1998) verified that project aims will have an effect on the VM participants' doings and the final result. Therefore, if SB is included as 
an objective, the VM process would work towards it.

\section{RESEARCH METHODOLOGY}

This research paper adopts a quantitative methodology where by questionnaire surveys were sent out to G7 contractors registered with CIDB currently practicing in Federal Territory of Kuala Lumpur which has the most numbers of G7 registered contractors in Malaysia. There was a total population of 1613 registered G7 contractors under CIDB (June 2015), thus, using Krejcie and Morgan (1970), a total of 310 random samples were required for this research. The unit of analysis for this research is the organisation that is the contracting company. 64 responses were received during the accepting period of the survey, which gives $20.65 \%$ out of the target sample. The response rate is lower compare to the expected response which is $30 \%$. Several factors might lead to the low response such as low interest in the topic and high work commitment which might has led to ignorance of this survey.

\section{FINDINGS AND DISCUSSION}

The data collected from the questionnaire were analyzed using Statistical Package for Social Science Research (SPSS). There were two types of analysis used for the data collected, which were descriptive analysis and inferential analysis.

\section{Background of respondents}

The majority of the respondents possessed bachelor degree $(60.9 \%)$ followed by master degree (31.3\%) and diploma (7.8\%). Additionally, majority of the respondents (38\%) has less than 5 years of working experiences in the industry followed by 5-10 years of experiences $(28 \%)$. The respondents whom are considered seniors in the industry and can provide valuable information to this research contributed to the remaining $34 \%$. This is shown in Figure 1 below.

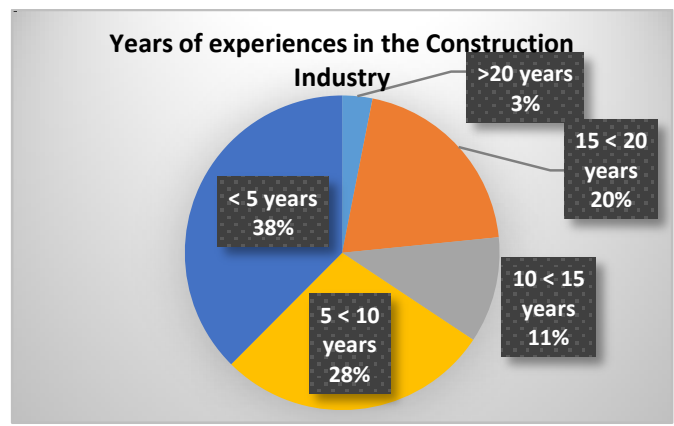

Figure 1: Years of Experiences of Respondents
In term of categories of registration with CIDB, majority of the contractors are registered under building construction $(51.6 \%)$ followed by civil engineering (35.9\%) and mechanical and electrical $(12.5 \%)$. The majority of the organisations $(77 \%)$ are currently involved in private projects and only $23 \%$ are involved in public or government projects.

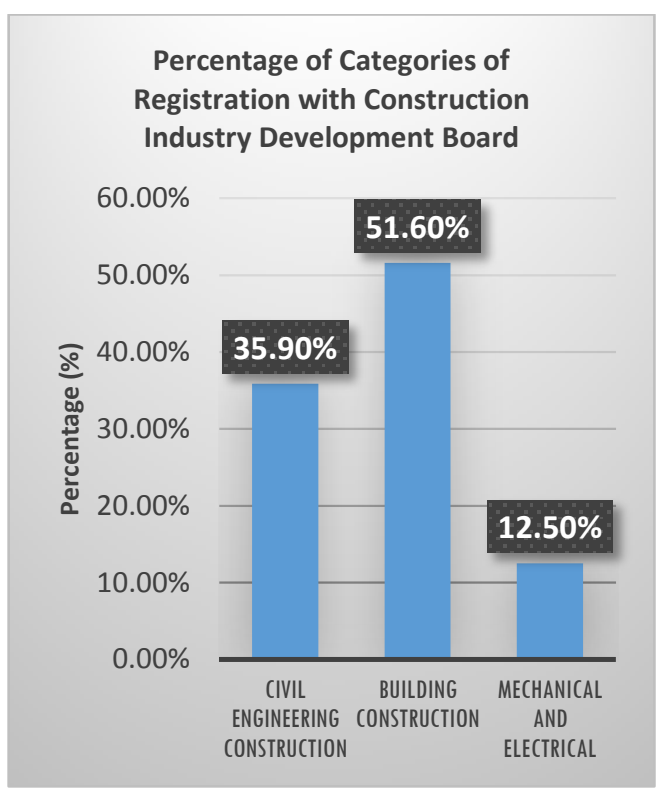

Figure 2: Percentage of Categories of Registration of Respondents with CIDB

\section{Development and practice of VM in Malaysia}

The research found that $47 \%$ of the respondents specify that VM is rarely being used in construction projects while $36 \%$ said that VM will be adopted more frequent in the industry. Meanwhile, $11 \%$ responded that VM will never be adopted compared to $6 \%$ said that VM has always been used in construction projects. Furthermore, the research found that majority of the respondents agreed that there are many obstacles which prevent the development and practice of VM in the industry, for which $25 \%$ said that there will always be obstacles and $44 \%$ said they occasionally faced with obstacles. Only 5\% indicated that they never had problems while $26 \%$ said that they rarely faced obstacles. When the respondents were asked on the importance of VM application, $75 \%$ of the respondents acknowledge of its significance and $25 \%$ denote that it is trivial. This is shown in Table 1 below. 
Table 1: Importance of VM to construction industry

\begin{tabular}{|c|c|c|c|c|c|}
\hline & & $\begin{array}{c}\text { Freq } \\
\text { uenc } \\
\mathrm{y}\end{array}$ & $\%$ & $\begin{array}{l}\text { Valid } \\
\%\end{array}$ & $\begin{array}{c}\text { Cumulativ } \\
\text { e } \%\end{array}$ \\
\hline \multirow{5}{*}{ Valid } & $\begin{array}{l}\text { Unimporta } \\
\text { nt }\end{array}$ & 0.0 & 0.0 & 0.0 & \multirow{5}{*}{$\begin{array}{r}0.0 \\
25.0 \\
70.3 \\
100.0\end{array}$} \\
\hline & Moderate & 16 & 25.0 & 25.0 & \\
\hline & Important & 29 & 45.3 & 45.3 & \\
\hline & $\begin{array}{l}\text { Very } \\
\text { Important }\end{array}$ & 19 & 29.7 & 29.7 & \\
\hline & Total & 64 & 100.0 & 100.0 & \\
\hline
\end{tabular}

The result of the needs of VM in construction industry commensurate with earlier research finding by Jaapar, Endut, Ahmad Bari, Takim (2009), which stated that majority of the total respondents in their research agreed that $\mathrm{VM}$ is applicable to the local construction industry.

Table 2 illustrates the Pearson Correlation test between the years of experiences in the construction industry and VM experiences in construction projects. Based on the result, the two variables had a positive Pearson correlation value which indicates there is a positive relationship among them. The more the working experiences of the respondents, the more the VM experiences of him in construction projects. One of the critical success factors for VM workshops in Malaysia is the experience of the stakeholders. (Mohamad Ramly, Shen and $\mathrm{Yu}, 2015)$ Thus, in order to achieve success in VM workshop, the selections for facilitator shall be made based on the experiences of stakeholders. The more the working experiences, the more the VM experiences he or she will have.

Table 2: Pearson Correlation test between years of experiences and VM experiences in construction projects

\begin{tabular}{|c|c|c|}
\hline & & $\begin{array}{c}\text { Years of } \\
\text { experience in } \\
\text { the construction } \\
\text { industry }\end{array}$ \\
\hline \multirow{3}{*}{$\begin{array}{l}\text { Years of } \\
\text { experience in the } \\
\text { construction } \\
\text { industry }\end{array}$} & $\begin{array}{l}\text { Pearson } \\
\text { Correlation }\end{array}$ & 1 \\
\hline & $\begin{array}{l}\begin{array}{l}\text { Sig. } \\
\text { tailed })\end{array} \\
\end{array}$ & \\
\hline & $\mathrm{N}$ & 64 \\
\hline \multirow{3}{*}{$\begin{array}{l}\text { Do you have any } \\
\text { experiences in } \\
\text { construction } \\
\text { projects using } \\
\text { VM? }\end{array}$} & \begin{tabular}{|l|} 
Pearson \\
Correlation \\
\end{tabular} & $.481^{\text {*** }}$ \\
\hline & \begin{tabular}{|l|}
$\begin{array}{l}\text { Sig. } \\
\text { tailed })\end{array}$ \\
\end{tabular} & .000 \\
\hline & $\mathrm{N}$ & 64 \\
\hline
\end{tabular}

\section{Development and Practice of SB in Malaysia}

The respondents were also asked on the development and practices of SB. The survey results illustrate that more than half or $53.1 \%$ the respondents are familiar with SB in construction projects, either occasionally or frequently involved. Meanwhile, $32.8 \%$ of the respondents hardly ever been involved in SB construction. Equally, $51.6 \%$ of the respondents agreed that the development of sustainability construction projects have been practicing frequently in Malaysia construction industry. In contrast, $48.4 \%$ of respondents have disagreed and that they claim that sustainability construction projects have rarely been practicing in Malaysia construction industry. Similar to the application of VM, the practice of $\mathrm{SB}$ is seen to face with obstacles, signifies by $80 \%$ of the respondents. Likewise, $86 \%$ of the respondents sanctioned the importance of SB to Malaysia construction industry. The survey result also specifies that $94 \%$ of the respondents agreed that the construction of SB should be promoted in Malaysia which indicates that they are aware of the importance of sustainability issues in the construction industry.

\section{Development and practice of VM-SB in Malaysia}

The descriptive statistical analysis conducted for this research reveals that most of the respondents $(68.8 \%)$ had never or rarely been involve in adopting $\mathrm{VM}$ into $\mathrm{SB}$ projects. Meanwhile, $25.0 \%$ of the respondents claim to have been occasionally involved in the VM-SB implementation and $6 \%$ have experiences in projects that implement VM and SB. This could be because the integration between the two variables may require the VM participants to have a high level of knowledge and understanding in VM as well as sustainability issues. Besides, the participants also need to have high consideration in the environmental sustainability, social sustainability as well as high level of economic sustainability in the project. It is believed that the best value for money and cost effective will be achieved if there is an economic sustainability (Md. Noor et al., 2015). However, there are still large samples of population which had no experiences in the integration. Thus, promotion between the integration is needed. However, despite the dubious impact of the VM-SB integration, majority of the respondents (73\%) are optimistic that such integration will help in promoting SB. The data could be verified as Abidin and Pasquire (2006) had emphasized that the unique characteristics and stages in VM 
contributes it towards a beneficial way to promote sustainability. It is believed that the greatest impact will be transpired upon the successful inclusion of sustainability issues into $\mathrm{VM}$ practices in the early stage of the project (Abidin and Pasquire, 2006).

This research also discovers a strong correlation between experiences in VM and experiences in SB, which is illustrated in Table 3 . With the Sig (2-Tailed) value equal to 0.000 (lesser than 0.05), and the positive Pearson Correlation value, these results prove that there is a relationship and significant difference between the two variables. When there are more VM experiences in construction projects, there would be more experiences in SB construction projects or vice versa. VM participants are required to have good understanding on VM as well as other construction knowledge such as sustainability. Thus, as the G7 contractors gain more VM experiences, there could be better chances for them to be involved in SB project. The similar situation could happen if the contractors had more SB project experiences; the chances for them to get involve into the VM workshop could be greater, particularly when the local construction industry is concern about sustainability issue lately. Therefore, the promotion towards VM and SB should be enhanced as it will intensify the integration.

Table 3: Correlation between experiences in $\mathrm{VM}$ and experiences in SB projects

\begin{tabular}{|c|c|c|}
\hline & & $\begin{array}{l}\text { Do you have any } \\
\text { experiences in } \\
\text { construction } \\
\text { projects using } \\
\text { VM? }\end{array}$ \\
\hline \multirow{3}{*}{$\begin{array}{l}\text { Do you have any } \\
\text { experiences in } \\
\text { construction } \\
\text { projects using } \\
\text { VM? }\end{array}$} & \begin{tabular}{|l|} 
Pearson \\
Correlation
\end{tabular} & 1 \\
\hline & $\begin{array}{l}\text { Sig. (2- } \\
\text { tailed) }\end{array}$ & \\
\hline & $\mathrm{N}$ & 64 \\
\hline \multirow{3}{*}{$\begin{array}{l}\text { Do you have any } \\
\text { experiences in SB } \\
\text { construction } \\
\text { projects? }\end{array}$} & \begin{tabular}{|l|} 
Pearson \\
Correlation
\end{tabular} & $.569^{* *}$ \\
\hline & \begin{tabular}{|l|}
$\begin{array}{l}\text { Sig. (2- } \\
\text { tailed) }\end{array}$ \\
\end{tabular} & .000 \\
\hline & $\mathrm{N}$ & 64 \\
\hline
\end{tabular}

Furthermore, the frequency of adopting VM and the increasing concern of sustainability issues in construction projects are also found to be correlated. Table 4 explains that when the project embraces VM frequently, the concern of sustainability issues will progress simultaneously. In other words, it is safe to say that the adoption of VM helps in promoting SB projects, and thus supports the VM-SB integration.

Table 4. Correlation between how frequent in adopting VM and development of adoption of sustainability construction projects

\begin{tabular}{|c|c|c|c|}
\hline & & $\begin{array}{l}\text { Based on } \\
\text { your } \\
\text { knowledge, } \\
\text { how } \\
\text { frequently } \\
\text { are VM } \\
\text { adopted in } \\
\text { construction } \\
\text { projects? }\end{array}$ & $\begin{array}{l}\text { Based on } \\
\text { your } \\
\text { knowledge, } \\
\text { how is the } \\
\text { development } \\
\text { of adoption } \\
\text { of } \\
\text { sustainability } \\
\text { construction } \\
\text { projects in } \\
\text { Malaysia? }\end{array}$ \\
\hline \multirow{3}{*}{$\begin{array}{l}\text { Based on } \\
\text { your } \\
\text { knowledge, } \\
\text { how } \\
\text { frequently } \\
\text { are VM } \\
\text { adopted in } \\
\text { construction } \\
\text { projects? }\end{array}$} & $\begin{array}{l}\text { Pearson } \\
\text { Correlation }\end{array}$ & 1 & $.478^{* *}$ \\
\hline & $\begin{array}{ll}\text { Sig. } & (2- \\
\text { tailed })\end{array}$ & & .000 \\
\hline & $\mathrm{N}$ & 64 & 64 \\
\hline \multirow{3}{*}{$\begin{array}{l}\text { Based on } \\
\text { your } \\
\text { knowledge, } \\
\text { how are the } \\
\text { developments } \\
\text { of adoption } \\
\text { of } \\
\text { sustainability } \\
\text { construction } \\
\text { projects in } \\
\text { Malaysia? }\end{array}$} & $\begin{array}{l}\text { Pearson } \\
\text { Correlation }\end{array}$ & $.478^{* *}$ & 1 \\
\hline & $\begin{array}{ll}\text { Sig. } & (2- \\
\text { tailed) }\end{array}$ & .000 & \\
\hline & $\mathrm{N}$ & 64 & 64 \\
\hline
\end{tabular}

\section{Performance Criteria of VM-SB integration}

The respondents were also asked to rate the required performance criteria of implementing $\mathrm{VM}$ in SB project, on a scale of 1 (disagree) to 4 (strongly agree). These performance criteria are based on Abidin and Pasquire (2005, 2007). The results are illustrated in Table 5 below and only the top five criteria will be discussed in this section. 
Table 5: Performance Criteria of Using VM in SB project

\begin{tabular}{|c|c|c|c|c|c|}
\hline Rank & Performance Criteria & $\mathrm{N}$ & Min & Max & Mean \\
\hline 1 & Optimum value of SB project can be achieved economically through VM & 64 & 2 & 4 & 3.06 \\
\hline 2 & VM helps in providing a long-term economic return for a SB project & 64 & 2 & 4 & 3.03 \\
\hline 3 & The quality of SB can be maintained or increased through VM implementation & 64 & 2 & 4 & 3.00 \\
\hline 4 & Different stages of VM helps in evaluating and increasing the performance of SB & 64 & 1 & 4 & 2.97 \\
\hline 5 & VM helps in proposing suitable construction method for SB & 64 & 2 & 4 & 2.92 \\
\hline 6 & VM helps in proposing sustainable construction materials for SB & 64 & 2 & 4 & 2.88 \\
\hline 7 & VM helps in eliminating unnecessary cost in SB construction project & 64 & 1 & 4 & 2.86 \\
\hline 8 & Optimum value of SB project can be achieved environmentally through VM & 64 & 1 & 4 & 2.83 \\
\hline 9 & $\begin{array}{l}\text { VM helps in minimizing conflicts occurred between cost and sustainability when } \\
\text { designing SB }\end{array}$ & 64 & 1 & 4 & 2.77 \\
\hline 10 & VM helps in reducing environmental damage caused by SB & 64 & 1 & 4 & 2.75 \\
\hline 11 & $\begin{array}{l}\text { Optimum value of SB project can be achieved in terms of social aspect through } \\
\text { VM }\end{array}$ & 64 & 1 & 4 & 2.73 \\
\hline 12 & VM helps in reducing social damage caused by SB & 64 & 1 & 4 & 2.61 \\
\hline
\end{tabular}

The respondents have selected 'Optimum value of $S B$ project can be achieved economically through $V M$ ' to be the most helpful criteria which for VM-SB integration. This is consistent with Abidin and Pasquire (2005) which have pointed out that VM has an abundance of techniques that could be used to reach the best solution in order to satisfy the client's needs at the lowest cost as possible. A next performance criterion is ' $V M$ helps in providing a long-term economic return for a $S B$ project'. This is also in relation to Abidin and Pasquire (2005) which claimed that that long term economic return can be achieved through excellent social and environmental performance of a building. Thus, by adopting VM-SB for projects, greater chances can be provided to the VM practitioners to achieve the targets mentioned, such as to minimize and reduce the environmental and social damage through recommending suitable site location, selecting suitable materials, determining elements and theme of design and choice of construction which in return could realize long-term economic return for SB project.

VM implementation will always seek for value for money and therefore in keeping with this aim, the third criterion selected is 'The quality of $S B$ can be maintained or increased through VM implementation'. According to IVM (2002), the concept of value relies on the relationship between the satisfaction of differing needs and resources used in doing so. The differing needs are likely to include aspects such as high quality, good indoor environment, durability, cheaper to maintain and user friendly. Thus, as enhancement technique, sustainability issue should be integrated in VM as they will affect the quality of the outcome of the building.

The fourth criterion is 'Different stages of $V M$ helps in evaluating and increasing the performance of $S B^{\prime}$. According to Abidin and Pasquire (2007), during the pre-workshop stage, the sustainability agenda could be included as part of the value drivers and soon will be revised and included in the statement of needs of client. During the VM workshop stage, function analysis will be performed to generate, select and develop the sustainability ideas and thus to work out into project proposal which have included sustainability issues in it. The process will then be continued with post workshop stage which aims to review on the proposal to seek for approval and implementation. 
The fifth ranked criterion is ' $V M$ helps in proposing suitable construction method for SB'. As previously mentioned, in order to achieve excellent social and environmental performance of a building, VM participants have the chances to recommend sustainable materials and construction method for a building (Abidin and Pasquire, 2005). Thus, the best suit construction method for sustainable projects could be selected throughout the VM stages. In addition, the impact of construction of buildings to the environment could be reduced through the selection of the best choice of construction method.

A further inferential analysis conducted to test on the correlation between the performance criteria and the educational background of the respondents showed that the higher the educational background of the respondents, the higher consent of the respondents on the performance of VM in SB projects. Table 6 indicates positive Pearson correlation values of education background and performance criteria of using VM in SB projects.

Table 6: Pearson correlation between education background and performance criteria of using $\mathrm{VM}$ in SB projects

\begin{tabular}{|c|c|c|}
\hline & & $\begin{array}{l}\text { Education } \\
\text { Background }\end{array}$ \\
\hline \multirow{3}{*}{$\begin{array}{l}\text { The quality of SB can } \\
\text { be maintained or } \\
\text { increased through VM } \\
\text { implementation }\end{array}$} & $\begin{array}{l}\text { Pearson } \\
\text { Correlation }\end{array}$ & .158 \\
\hline & $\begin{array}{l}\text { Sig. } \\
\text { tailed) }\end{array}$ & .214 \\
\hline & $\mathrm{N}$ & 64 \\
\hline \multirow{3}{*}{$\begin{array}{l}\text { Different stages of } \\
\text { VM helps in evaluate } \\
\text { and increase the } \\
\text { performance of SB }\end{array}$} & $\begin{array}{l}\text { Pearson } \\
\text { Correlation }\end{array}$ & $.334^{* *}$ \\
\hline & $\begin{array}{l}\text { Sig. } \\
\text { tailed })\end{array}$ & .007 \\
\hline & $\mathrm{N}$ & 64 \\
\hline \multirow{3}{*}{$\begin{array}{l}\text { Optimum value of SB } \\
\text { project can be } \\
\text { achieved } \\
\text { economically through } \\
\text { VM }\end{array}$} & $\begin{array}{l}\text { Pearson } \\
\text { Correlation }\end{array}$ & $.268^{*}$ \\
\hline & $\begin{array}{l}\text { Sig. } \\
\text { tailed) }\end{array}$ & .032 \\
\hline & $\mathrm{N}$ & 64 \\
\hline \multirow{3}{*}{$\begin{array}{l}\text { VM helps in } \\
\text { proposing } \quad \text { suitable } \\
\text { construction method } \\
\text { for SB }\end{array}$} & $\begin{array}{l}\text { Pearson } \\
\text { Correlation }\end{array}$ & $.371^{* *}$ \\
\hline & $\begin{array}{l}\text { Sig. } \\
\text { tailed })\end{array}$ & .003 \\
\hline & $\mathrm{N}$ & 64 \\
\hline \multirow{3}{*}{$\begin{array}{l}\mathrm{VM} \text { helps in } \\
\text { providing a long-term } \\
\text { economic return for a } \\
\text { SB project }\end{array}$} & $\begin{array}{l}\text { Pearson } \\
\text { Correlation }\end{array}$ & $.333^{* *}$ \\
\hline & $\begin{array}{l}\text { Sig. } \\
\text { tailed })\end{array}$ & .007 \\
\hline & $\mathrm{N}$ & 64 \\
\hline \multicolumn{3}{|c|}{$\begin{array}{l}\text { **. Correlation is significant at the } 0.01 \text { level (2- } \\
\text { tailed). } \\
\text { *. Correlation is significant at the } 0.05 \text { level (2- } \\
\text { tailed). }\end{array}$} \\
\hline
\end{tabular}

There are 4 criteria out of the total 5 criteria which have significant difference with education background. Thus, it can be concluded that there is correlation between education backgrounds with performance of $\mathrm{VM}$ in SB project. This may due to as the respondents gains more education; they tend to have more understanding and knowledge about VM and sustainability issues. Thus, they are aware of the performance of VM in SB projects. Therefore, the education of benefits of VM towards sustainability issue should be introduced to the industry.

\section{CONCLUSION}

In conclusion, the research discovered there is a positive integration between the concepts of VM and sustainability, consistent with previous researches conducted for the past ten years. However, the existing practices of VM and SB as well as their integration are not in the expectation. Many construction players, particularly the G7 contractors are not completely ready in putting $\mathrm{VM}$ into practice VM for which most of them had no prior experience in the application of VM in their projects, despite the majority agreement that $\mathrm{VM}$ is applicable to the local construction industry. In the meantime, the implementation of SB in Malaysia is embryonic compared to the last five years. Barriers that preventing SB implementation should be identified and ways to overcome it could be suggested. From this research, it is undoubtedly that SB is gaining better attention as the industry has realized the importance of sustainability issues to the country. Therefore, there are still rooms for improvement for sustainability construction projects in Malaysia. The VM-SB integration is novel and innovative hence not many practitioners have such experience of adopting the concept. It requires the VM participants to have exceptional level of knowledge and understanding in VM as well as sustainability issues. Therefore, seminars and conferences could be organized to expose the knowledge as well as to help in advocate the integration. Nevertheless, there is no firm opinion on the VM-SB integration which could be due to the uncertain outcomes and impact to the industry.

The potential of $\mathrm{VM}$ in delivering sustainable project and in contributing to the increasing sustainability value of a project should be introduced to the industry. The respondents also had a positive outlook towards the VM-SB integration that such move will facilitate in promoting SB practices. The greatest impact will be realized when the 
practitioners are given the opportunity to include sustainability issues into VM processes at the early stage of the project. Additionally, the more VM experiences that a practitioner has, the greater the chances for him or her to be involved in SB project. When VM is frequently adopted, sustainability construction projects will become more develop and therefore the VM-SB integration is nascent.

\section{REFERENCES}

Abd-Karim, S.B. (2016). The Application of Value Management on Private Projects. QS Link 2/2016, 33-36. Board of Quantity Surveyors Malaysia Bulletin.

Abd-Karim, S.B., A-Rahmin, R.A., Mohd Danuri, M.S. and Mohamed, O. (2014). Developing the Value Management Maturity Model $\left(\mathrm{VM} 3^{\odot}\right)$. Journal of Design and Built Environment, 14(1), 1-10.

Abidin, N. Z. \& Pasquire, C. L. (2005). Delivering sustainability through value management: Concept and performance overview. Engineering, Construction and Architectural Management, 12(2), 168-180.

Abidin, N. Z., \& Pasquire, C. L. (2007). Revolutionize value management: A mode towards sustainability. International Journal of Project Management, 25(3), 275282.

Abidin, N. Z. (2009). Sustainable Construction Practices in Malaysia. Global Warming, 385-398. doi:10.1007/978-1-4419-1017$2 \_24$

Abidin, N. Z., \& Said, I. (2006). Involvement of Sustainability Issues in Value Management: Requisite Factors.

Akadiri, P. O., Chinyio, E. A., \& Olomolaiye, P. O. (2012). Design of a sustainable building: A conceptual framework for implementing sustainability in the building sector. Buildings, 2(2), 126-152.

Al-Saleh, Y. M., \& Taleb, H. M. (2010). The integration of sustainability within value management practices: A study of experienced value managers in the GCC countries. Proj Mgmt Jrnl, 41(2), 50-59. doi:10.1002/pmj.20147

Bahaudin, A.Y, Elias, E.M, Saifudin, A.M. (2014). A Comparison of the Green Building's Criteria. In Proceedings of the Emerging Technology for Sustainable Development Congress (ETSDC 2014), Bangi, Malaysia, 5 August 2014.

Bala, A. (2017). Sustainable Development: The need of hour. National Journal of Multidisciplinary Research and Development, 2(2), 40-42.
Barton R, Jones D and Andersen H (1999), Incorporating the Values of Ecologically Sustainable Development into Project Definitions using Soft Value Management. Proceedings of the International Conference of the Institute of Value Management, Managing Sustainable Values, Hong Kong.

British Standard, EN 12973 (2000). BS EN 12973: Value Management.

CIDB Malaysia. (2007). Strategic recommendations for improving environmental practices in construction industry. Kuala Lumpur: CIDB Publisher.

Daly, H.E. (1990). Sustainable Development: From Concept and Theory to Operational Principles. Population and Development Review, 16, 25-43

Darus, Z. M., Hashim, N. A., Salleh, E., Haw, L. C., Rashid, A. K. A., \& Manan, S. N. A. (2009). Development of rating system for sustainable building in Malaysia. WSEAS Transactions on Environment and Development, 5(3), 260-72.

El-Alfy, A. J. (2010). Design of sustainable buildings through Value Engineering. Journal of Building Appraisal, 6(1), 69-79.

GSB (2009). Green Building Index. Available at: http://www.greenbuildingindex.org

Häkkinen T, Belloni K. Barriers and drivers for sustainable building. Build Res Inform 2011;39 (3):239-55.

Hayles, C. S., Graham, M. \& Fong, P. W. S. (2010). Value Management as a framework for embedding sustainable decision making. Proceedings of ICE Municipal Engineer,163(1), 43-50.

Hill, R.C., \& Bowen, P.A. (1997). Sustainable construction: principles and a framework for attainment. Construction Management \& Economics, 15(3), 223-239.

Isa, N.K.M, Samad, Z. A., \& Alias, A. (2014). A Review on Sustainability Principles of Building: Formulation of a Theoretical Framework. Journal of Surveying, Construction and Property (JSCP), 5(1).

Jaapar, A. And Abd-Karim, S.B. (2005). Value Management: In general. Value News. Institute of Value Management Malaysia (IVMM). Vol.1/March.

Jaapar, A., Maznan, \& Zawawi, M. (2012, November). Implementation of Value Management in Public Projects. Paper presented at ASIA Pacific International Conference on Environment-Behaviour Studies, Mercure Le Sphinx Cairo Hotel, Giza, Egypt.

Jaapar, A., Endut, I. R., Ahmad Bari, N. A., \& Takim, R. (2009). The Impact of Value Management Implementation in Malaysia. 
Journal of Sustainable Development, 2(2), doi:10.5539/jsd.v2n2p210.

Karunasena, G., Rathnayake, R.M.N.U. and Senarathne, D. (2016). Integrating sustainability concepts and value planning for sustainable construction, Built Environment Project and Asset Management, 6(2), 125-138

Khalil, N., Nizam Husin, H., \& Nawawi, H. (2011, June). An Analytical Literature: Strategic Improvement of Sustainable Building Performance Tool for Malaysia's Higher Institutions. Paper presented at ASEAN Conference on EnvironmentBehaviour Studies, Savoy Homann Bidakara Bandung Hotel, Bandung, Indonesia.

Kibert, C. J. (2008). Sustainable construction: Green building design and delivery. Hoboken, NJ: John Wiley \& Sons.

Krejcie, R. V., \& Morgan, D. W. (1970). Determining sample size for research activities. Educational and psychological measurement, 30(3), 607-610.

Loukola, O. and Kyllönen, S. (2005). The philosophies of sustainability. In Anneli Jalkanen \& Pekka Nygren (eds.) 2005. Sustainable use of renewable natural resources- from principles to practices. University of Helsinki Department of Forest Ecology Publications.

MAHB (2008). Value Management Manual, Malaysia Airports Holdings Berhad, Malaysia.

Md. Noor, N. F., Kamruzzaman, \& Ab. Ghaffar, N. (2015). Sustainability Concern in Value Management: A Study On Government's Building Project. International Journal of Scientific \& Engineering Research, 6(1).

Mohamad Ramly, Z., Shen, G. Q., \& Yu, A. T. (2015). Critical Success Factors for Value Management Workshops in Malaysia. Journal of Management in Engineering, 31(2).

Oke A.E., Aigbavboa C.O. (2017) Drivers of Sustainable Value Management. In: Sustainable Value Management for Construction Projects. Springer, Cham
Pasquire, C. L., \& Mauro, K. (2001). A comparison of value management methodology in the UK, USA and Japan. Journal of Financial Management of Property and Construction, 6(1), 19-29.

Phillips M.R. (1999), “Towards sustainability \& consensus through value management: case study", Managing Sustainable Values, Proceedings of the International Conference of the Institute of Value Management, 6 - 7 May, Hong Kong.

Platova, Y. (2013). Is the Concept of Sustainable Development a Contemporary Ideology? Proceedings of FIKUSZ '13 Symposium for Young Researchers, 2013, Obuda University Keleti Faculty of Business and Management, Hungary, pp 5566.

PROKOM (2012). Value engineering application guidelines for public projects. Cawangan Pengurusan Projek Kompleks, Jabatan Kerja Raya Malaysia, Kuala Lumpur.

SAVE International. (2007). Value standard and body of knowledge. Retrieved July 9, 2007, from http://www.valueeng.org/pdf_docs/monographs/vmstd.pdf

Shari, Z., \& Soebarto, V.I. (2012). Delivering Sustainable Building Strategies in Malaysia: Stakeholders' Barriers And Aspirations. Universiti Putra Malaysia Alam Cipta, 5(2).

Yeomans, P. Y. (2002). Environmentally sustainable development plus value management equals results minus rhetoric. In International Conference of the Institute of Value Management (pp. 29-30).

Zainul-Abidin, N., \& Pasquire, C. L. (2003). Moving towards sustainability through value management. In: CIB Joint International Symposium, Singapore, October 2003, Singapore.

Zainul Abidin, N. (2010). Investigating the awareness and application of sustainable construction concept by Malaysian developers. Habitat International, 34(4),421-426. doi:10.1016/j.habitatint.2009.11.011 